\title{
South Africa and the High Commission Territories during the Second World War: Politics and Policies Affecting War Mobilization
}

\section{Deborah Shackleton}

The political, economic, social and military developments in the High Commissioned Territories (HCT) throughout much of the $19^{\text {th }}$ and $20^{\text {th }}$ centuries were highly influenced by their southern neighbor. During the Second World War, these developments have a rather direct impact on British decision-makers in London and in southern Africa especially with regards to war mobilization, African military recruitment and labor issues. Much of what will be discussed in this paper must be understood in the context of British imperial organization and demands as formulated and dictated by the Colonial Office in London with coordination with the Office of the High Commissioner in South Africa who was responsible for the overall care and protection of the HCT. However, historical precedent, economic necessity, military exigencies, paternalism, and racial ideology also drove policy decisions regarding mobilization during WW II.

Without going into great detail about the position of the British Empire in 1939 to defend itself against German aggressions, it is still important to accept in principle that Great Britain did not have the resources and manpower to fight the fight

alone. As an island nation that hated to be dragged into the messy affairs of the continent, England wanted to confine herself to her own interests. By 1938 the British Army was designed primarily for home defense and was unprepared for rearmament and mobilization. ${ }^{1}$ Many in positions of power questioned the role of imperialism and its subsequent militarism. Predatory imperialism violated the new ideas of liberalism, pacifism, and a growing sense that colonies should move towards selfgovernment. ${ }^{2}$ Despite the lack of preparation and will to fight another brutal war, Britain would call upon its global dominions to answer the call of collective security against Hitler's transgressions.

Ibid., p 345. 
As you are all intimately aware, South Africa's position within the British Empire under the ruling government in 1939 was ambiguous. South African journalist W. van Heerdan in a paper delivered at a conference on South African politics referred to "the gigantic struggle that dominated this country's political life and thought for more than a century and a half...the struggle for paramountcy between the British imperial and the South African national idealisms. Thus, with a characteristic Afrikaner perspective, he equated South African English-speakers as British imperialism and Afrikaner nationalism with South African nationalism. All issues, he went on, are subordinated to this one issue. The tensions emanating from this political struggle for political control impacted defense legislation and the assignment of armed forces abroad as studied by Kenneth Grundy in the period from 1912 to 1976. South Africa's entry into the Second World War exacerbated these problems and heightened tensions in South Africa, the region and one might even argue in the neighboring High Commissioned Territories.

When Britain declared war against Germany, the South African cabinet met to consider the war issue and whether to remain neutral or commit South African armed forces. When the vote was finally taken, by 80 to 67 the House of Assembly resolved that the Union sever its relations with Germany and "to refuse to adopt an attitude of neutrality" in the conflict between Britain and Germany. It further resolved that the Union carry out obligations to friends and associates in the British Commonwealth of Nations and that "the Union should take all necessary measures for the defense of its territory and South African interests, and the Government should not send forces overseas as in the last war." ${ }^{\prime 4}$ As a result Prime Minister General J.B.M. Hertzog, the leader of the Afrikaner opposition to the war, resigned his position the next day and General Smuts became the Prime Minister in September 1939. The decision to support the war effort drove a wedge into a significant segment of South Africa's white population and solidified Nationalist misgivings about Smuts' intentions of dragging the country into another foreign conflict.

The Afrikaner constituency was extremely critical of Smuts' implementation of "war measures" and resisted him at every turn. ${ }^{5}$ From the beginning of increased tensions in Europe, there had been rumors of a rebellion by

Kenneth W. Grundy, "The Evolution of a White South African Nation as Reflected in the Controversy Over the Assignment of Armed Forces Abroad, 1912-1976" in Ohio University: Center for International Studies Papers in International Studies Africa Series No. 33, 1978, p 5.

Ibid., p 23.

M. Roberts and A.E.G. Trollip, The South African Opposition, 1939-1945: An Essay in Contemporary History (London: Longmans, Green \& Co, 1947), intro. 
the Nationalists who were sympathetic to the German cause. ${ }^{6}$ They were set against any active participation in a war that South Africa was not militarily threatened. ${ }^{7}$

For Smuts there would be little time to worry about internal political squabbles; the war was spreading to Africa. On 16 March 1940 General Sir Archibald Wavell, Commander-in-Chief (C-in-C) Middle East, flew to South Africa to see Smuts about sending troops to Kenya. ${ }^{8}$ Smuts agreed to raise a brigand and three squadrons of aircraft for service in Kenya. ${ }^{9}$ While Europe puzzled over the "Phoney War," Italy contemplated joining the fray. On 10 June Italy declared war on Britain, and allied itself with Nazi Germany against a prostrate France. South Africa was now at war with Fascist Italy. Smuts took inventory of South Africa's state of military readiness. He was not pleased with what he found-South Africa was completely unprepared for war. ${ }^{10}$ The Army and the Air Force were under strength.

The 1912 Defence Act was examined and challenged on its ambiguous language regarding union responsibilities on the continent. Smuts asserted "if the need arises, either for the defense of the Union or for assistance to the British territories right up to the equator, it is the policy of the Government to help and extend operations as far as Kenya and Tanganyika. ${ }^{12}$ Soon after the declaration of war, Smuts began a massive recruitment effort to create a volunteer force for action beyond the Union's frontiers. New recruits were expected to take the General Service Oath that angered Afrikaner nationalists. It read:

That I will be faithful and bear true allegiance to His Majesty King

D.W, Kruger, The Making of a Nation (Johannesburg and London: Macmillan, 1969), p 204.

This policy was outlined by Mr Oswald Pirow, Minister of Defense, in 1935 when he stated the Union would never participate in any imperial defense scheme and that even a declaration of war by the Sovereign did not automatically involve South Africa. A. Clayton, The British Empire as a Superpower, 308; H.J. Martin and Neil Orpen, South Africa at War (Cape Town, Johannesburg and London: Purnell, 1979), p 7.

Ibid., p 101.

John Keegan, The Second World War (New York: Penguin Group, Viking Division, 1989), p 321. Dan Pienaar a veteran of the Boer War against the British led the force.

J.S.M. Simpson, South Africa Fights (London: Hodder and Stoughton, 1941), 94101; and W.K. Hancock, Smuts, The Fields of Force, 1919-1950. Vol. II (Cambridge: University Press, 1968), pp 328-32. was in a sorry plight. Martin and Orpen, South Africa at War, p 27. 
George VI and his heir and successors according to law...that I will perform to the Best of my ability the duties assigned to me as a volunteer member of the UDF...that I will serve in Africa for the duration of the present war and for a Period of six months thereafter unless otherwise legally discharged. ${ }^{13}$

Later, in 1943, this Red Oath, as it became known, was amended to read simply "anywhere." Novelist Alan Payton in Too Late the Phalarope (1953) tells how a young Afrikaner recruit felt about the oath:

But the red oath, to those who would not take it, meant only one thing, That the wearer of it was a Smuts man, a traitor to the language and Struggle of the Afrikaner people, and a lick-spittle of the British Empire and the English King, fighting in an English war that no true Afrikaner would take part in. So some wore the flashes of the red oath And some wore none, and this caused great bitterness.... ${ }^{14}$

Smuts furthered angered Afrikaner nationalists by stating he was not averse to using African soldiers if white recruitment fell short of British quotas. In a country with only a limited white population, so many volunteer brigades and units could not possibly be maintained without the assistance of the black population of South Africa and the HCT. In view of the fact that levels of education and technical knowledge placed the white automatically in "leadership" class, it was militarily self-evident that the lower ranks would have to be reinforced with African recruits. ${ }^{15}$ Since the majority of white opinion was against the arming of Africans, Smuts decided to reform the Cape Corps (2 Divisional Signals Company and 1 and 3 Brigade Signals Companies) and organize a new "Native Labour Corps."16 Recruitment commenced on 1 June 1940 under the auspices of the Non-European Army Services. Later in the war, Smuts declared he was ready to enlist nonEuropeans for combatant service as needed, "If it comes to a question of defending South African territory against the Japanese menace, [] will arm every African and Coloured soldier that is available. ${ }^{17}$ The political controversy over the employment

13

Ibid., p 30 .

Alan Paton, Too Late the Phalarope (New York: Charles Scribner's Son's, 1953). pp 32-33.

Martin and Orpen, South Africa at War, 59. Kathryn Jean Gibbs, "Demobilisation After World War II: The Process and Politic of Reinstating Union Defence Force Volunteers into Civilian Life, 1943-1948," History Honours Paper, University of South Africa, January 1990, gives the following figures: Out of an estimated population of $11,416,000$, a total of only 345,029 men and women enlisted. Of these, 197,875 were white males, 24,640 white females; 45,783 Cape Corps and Indian and Malay Corps; and 76,731 Native Military Corps.

Ibid.

In March 1942, Smuts declared that if the Japanese attacked the Union, he would arm "Natives and Coloureds" for the defense of the country. Hancock, Smuts : The 
of black combatants against white soldiers, regardless of ethnic background, was central in the minds of most Afrikaners. Historically, the issue had never been fully resolved. Opposition was stiff from leaders such as Defense Minister Mr. O. Pirow and Chief of the South African General Staff, Sir Pierre van Ryneveld. ${ }^{18}$

British policy-makers tried to avoid a confrontation in South Africa by allowing General Smuts to maneuver through the political rapids of dissent. The influence of Smuts on the Colonial Office was profound. There were many occasions when the British government felt compelled to modify their plans based on recommendations of white leaders in South Africa. ${ }^{19}$

It was essential from a British perspective that South African forces immediately reinforce the allied effort in East Africa. Italian military strength in East Africa was assessed at a total of some 200,000 metropolitan and colonial troops. ${ }^{20}$ Smuts agreed to dispatch infantry and air forces to Kenya in July 1940. On their arrival in East Africa the following message from the King was read to South African troops:

Once again forces from the Union of South Africa have come to East Africa to take part with other members of the British Common-Wealth in the fight for the future of their own country and for the Safety of all freedom-loving peoples. As you enter the field of war, I send my best wishes, confident that with your help our cause will Triumph. ${ }^{21}$

Men from all over the empire enlisted by the thousands in the imperial forces. Australians, Maoris from New Zealand, Malayans, Jews and Arabs, Egyptians, Indians, and Africans rallied to the Allied cause. British colonial officials in southern Africa and the African leaders in the HCT realized that their fate was closely tied to what transpired in South Africa. Smuts eventually committed South African troops (black and white) to the North African, the Middle East and European campaigns. If mobilization proceeded as it had during World War One, the HCT would be expected to supply manpower to South African

Fields of Force, 370; Donald Molteno, "Arming African Soldiers," The Bantu World, 21 Mar 1942, p 4.

General Ryneveld's extraordinary influence on military planning and mobilization during the war resulted in "inevitably ill-considered decisions best illustrated by extraordinary waste of non-white manpower throughout the war and their limitation to a non-combatant role against the intentions of Smuts." Martin and Orpen, South Africa at War, Vol. 7, forward.

J. Hatch, The History of Britain in Africa (London: Andre Deutsch Limited, 1969), p 237.

A. Clayton, The British Empire as a Superpower, 1919-1939. Athens, Georgia: The University of Georgia Press, 1986, p 317. 
military units. As events unfolded during the first months of the war, it looked as if history was indeed going to repeat itself.

As mentioned earlier, the mobilization plans formulated in South Africa impacted on military policy and preparations in the HCT. My case study will look more closely at just one of these protectorates, Bechuanaland. Archival material in London and Botswana indicate that the High Commissioner at Cape Town, along with the Resident Commissioners, were influential in shaping military policy regarding mobilzation and the employment of Africans during the war. Taking South Africa's lead, colonial administrators in the Protectorate offered to recruit volunteers for the South African Native Military Corps (SANMC) and other security forces in South Africa. The High Commissioner, Lord Harlech, addressing the BaTswana leadership in July 1940, was completely supportive of this effort:

There is no opportunity at present for service in Europe. But then native units are needed for service in the Union or in other parts of Africa, we shall try to arrange for the Territories to have the opportunity of taking part. The Imperial Government does not at present wish us to raise a separate unit. ${ }^{22}$

Thus, both Basutoland and Bechuanaland contributed to early military efforts organized in South Africa. The first group that received reinforcements was the South African Native Police Force.

At the outbreak of war in 1939, no immediate attempt had been made to recruit Africans to act in any capacity in the South African armed forces. By 1940, however, it became clear to the government that many whites were protecting various essential services within the country. Such duties, it was decided, could well be carried out by Africans. The government accordingly decided to recruit 4,000 blacks for the purpose of guarding such places within the Union as they thought necessary to protect. In the past, the Police Force in South Africa was composed of both Europeans and Africans. ${ }^{23}$ The African members of the Force, although they did not handle rifles, underwent the same peace-time training as European members. ${ }^{24}$ It was made clear from the beginning that blacks would not be equipped with rifles, their arms were those normally carried by the black police, namely a short assegai and knobkerries. ${ }^{25}$ During the war, their duties were focused on the maintenance of law and order, securing vital installations, and the prevention of

BNA S 135/7 War with Germany. Letter from C.N.A. Clarke to Chief Tshekedi and 7 Apr 1941. Chief Bathoen,

In 1939 there were 7,754 Europeans and 3,676 non-Europeans. Official Yearbook of the Union of South Africa, No. 22 (1941), p 390.

"For the Defence of South Africa," The Bantu World, 27 Apr 1940, p 4. 
sabotage in the Union. ${ }^{26}$ Recruiting for the Native Military Police Force was stopped in the Bechuanaland Protectorate when the Director for Non-European Services (S.A.) organized the Native Military Guard.

In July 1940 authority was received to create four battalions of Native Military Guards. Zulus from Natal were intended to form the first battalion, northern Transvaal blacks for the second battalion, Xhosa from the Transkei for the third, and Africans from the urban areas for the Witwatersrand Battalion. ${ }^{27}$ Initially recruiting blacks for the Military Guards did not do well. The quota of 4,000 was eventually filled with recruits from the northern Transvaal and the HCT, including Bechuanaland. The lack of response and resentment regarding pay and allowances offered to the Guards, led to a unit for Africans organized on proper military lines, with uniforms, pensions and disability allowances. ${ }^{28}$ This was called the Native Military Corps (SANMC).

In November 1940, recruitment for the SANMC was authorized in the Bechuanaland Protectorate and the other HCT. ${ }^{29}$ The new unit was under the command of Col. E.T. Stubbs. South African military planners realized that there could be training problems with recruits enlisted outside the Union. It was suggested that officers from the Territories be incorporated into the newly formed units to help with language and training exercises. Hoping to build enthusiasm for this effort, Bechuanaland officials offered to establish a recruiting depot and training camp at Machaneng (a police camp in Bechuanaland), but South African officials decided against it because of the costs and inconvenience. ${ }^{30}$ As it turned out, recruiting was delayed in the Protectorate due to the lack of barrack accommodations in the Union.

Resident Commissioner, C. Arden-Clarke, recognized that the success of any recruiting campaign for the SANMC would depend on first winning over the BaTswana chiefs and influential headmen. From the beginning, there were many questions regarding organization, pay and leadership. In particular, the proposed organization of the SANMC did not permit training in "tribal units," or of service

One of their main duties was to keep a check on all people known to be pro-Nazi. Additionally, they were charged with implementing Emergency Measures against sabotage. Africans generally replaced regular policemen, who had been called up for active service. Martin and Orpen, South Africa at War, p 59.

M. Roth, "If You Give Us Rights," 992.

Ibid. Smut Papers, 6/41, B. Nicholson to D.L. Smit, 10 Feb 1941.

For history on the SANMC see Ian Gleeson, The Unknown Force: Black, Indian and Coloured Soldiers Through Two World Wars (South Africa: Ashanti Publishing, 1994) and Louis Grundlingh, "The Participation of South African Blacks in the Second World War" (D. Litt et Phil Thesis, 1986). 1940. 
thereafter with their fellow countrymen except to a very limited extent. ${ }^{31}$ Among white South African detachments, blacks were assigned as laborers and transport drivers. Later, they were integrated into artillery, smoke and ammunition units. The BaTswana leaders had already made it known they wanted separate "tribal" units, but the Resident Commissioner explained there were no funds for distinct HCT units. They argued there would be little or no recognition for BaTswana soldiers if they were amalgamated among the 80,000 or more recruited Africans from the Union that served during the war. The chiefs were also afraid that BaTswana volunteers might receive differential treatment from South African military officers and non-commissioned officers. In order to alleviate their fears, the BaTswana diKgosi (chiefs) were invited to Welgedacht, South Africa to review how the training was being organized and see for themselves the accommodations, food, uniforms, etc. that their men would be given. ${ }^{32}$

The visit at Welgedacht alleviated some of the chiefs' fears. They agreed that the Union had better facilities for training Africans than the Bechuanaland Protectorate: the organization of the camp was good and the food was excellent. However, they continued to have reservations. There was great prejudice against joining in with the Union. Many ex-soldiers remembered WWI and the discriminatory practices of Union army officials that had caused such resentment among some soldiers that they refused to accept war medals offered by the British. ${ }^{33}$ In particular, they resented white objections against the arming of blacks and their forced non-combatant status. The chiefs realized that the Union government was opposed to the formation of a Protectorate unit, but they wanted to be able to say that Bechuanaland contributed separately to the preservation of liberty, international order and tolerance against the forces of dictatorship, aggression and racial discrimination. Additionally, it was hoped by many Africans that the war would bring about a change in colonial policy regarding the incorporation of Bechuanaland into the Union of South Africa if they defended British war aims. Tshekedi Khama (Regent of the BaNgwato) summarized their position in a letter to the Resident Commissioner in February 1941:

The Chiefs of the Bechuanaland Protectorate together with their people have desired from the out-break of hostilities to take their full share in Britain's War effort and immediately tendered their services. Our desire has always been to take our place by the side of Great Britain and her Allies in the field of war. ${ }^{34}$

BNA S 135/3 Box No. 135, Native Military Corps: Terms and Conditions of Service.

BNA S 135/7 War With Germany: Chief Tshekedi's Proposal for the Formation of Native Corps.

BNA S $135 / 7$ War with Germany. Letter from Khama to Resident Commissioner, Mafeking, 26 Feb 1941. 
It was also felt that if there was no intention of sending Africans out of the Union, which was the initial plan although it was quickly abandoned, they might as well say home and contribute to local defense. ${ }^{35}$ Only seven hundred men out of a total of $80,000^{36} \mathrm{NMC}$ that served during the war were from Bechuanaland; the BaTswana never enthusiastically supported the South African recruitment

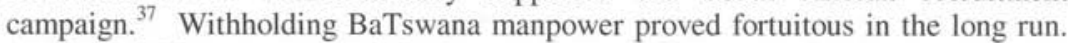
As the British manpower crisis deepened, new efforts were implemented by the British War Office to find volunteer forces for labor duties in North Africa and the Middle East. Although colonial backwater possessions, the combined manpower strength of the Bechuanaland Protectorate and the other HCT was significant.

In spite of the successes against the Italian forces in Ethiopia and British Somaliland, the occupation of Eritrea and Italian Somaliland, the sinking of the Bismarck and the still unexplained flight of Hitler's deputy, Rudolph Hess, to Scotland, the war was not going well for Britain and its allies in 1941. The British withdrew from Greece and after a humiliating military fiasco were driven out of Crete. On 22 June the apparently invincible Hitler launched his invasion of Russia long a two thousand mile front. By 3 September Leningrad was almost encircled. Then contradicting the mystique of British supremacy at sea, the aircraft carrier Ark Royal was sunk off Gibralter. ${ }^{38}$ With Rommel's Afrika Korps moving across North Africa, the British manpower crisis reached new heights in mid-1941.

With the British army thus suddenly faced with an urgent need for combatants and labor units at different battle-fronts in Europe, the Middle East and North Africa, officials approached South Africa for more men. However, the Union had difficulty recruiting additional European fighting forces among whites. ${ }^{39}$ General Smuts when he visited the Middle East in March 1941 had warned General Wavell that white South African manpower was not unlimited. As far as the South African army was concerned, the prospect of South African troops operating in the Western Desert in conjunction with experienced Imperial forces not raised immediate problems regarding organization but, given Union racial attitudes and policies, also raised questions relating to the employment of non-Europeans. Maximum use was already being made of the Cape Corps and SANMC for military transport and other support duties at home in order to release Europeans for combat

BNA DCF 7/5, Formation of African Contingent Native Military Corps, Letter from Nettleton to Forsyth Thompson, 23 Dec 1940.

Another estimate puts the figure at about 500. Sir John Shuckburgh, "Civil History of the War of 1939-1945 South African High Commissioned Territories." Official Paper. (Great Britain: Commonwealth Relations Office, 1947), 8; BNA S 136/3, Memorandum on African Pioneer Corps, No. 64. Ian Gleeson, The Unknown Force, 111. 
duty. ${ }^{40}$ In the face of these problems, Smuts decided, against much opposition. To replace some of the white gun crews guarding the extensive coastlines of South Africa with Zulus in order to release even more whites for service elsewhere. In August 1941 Zulus were recruited for the $21^{\text {st }}$ Field Regiment, and were first stationed in Durban. The administration convince opponents that they were noncombatants despite the Director of Artillery Training's opinion that, "no member of a gun crew can be considered as a non-combatant... and as the training of gunners as such is, it is misleading to suggest that they [non-white gunners] are not being used as combatants." ${ }^{41}$ The Union was obviously doing everything it could to avoid committing Africans for military service outside its borders. It is interesting to note that when General Wavell requested 28 Native Military Corps Companies for pioneer duties, South Africa refused on grounds that NMC was not a labor corps. ${ }^{42}$ According to General van Ryneveld, South African blacks would be unwilling to volunteer strictly for labor duties, and if they did there would be repercussions on the farms and in the mining industry. ${ }^{43}$ Frustrated with South African reticence, General Wavell requested that labor requirements be met with troops from other British possessions in Africa, specifically the HCT because they were better suited to the fluctuations of cooler Mediterranean climates. ${ }^{44}$

Thus, it was Britain's critical shortage of manpower, and the Union's reluctance to recruit strictly "labor units" for service in North Africa and the Middle East that forced the British to reconsider its policies and locate new sources of manpower. In Bechuanaland, Tshekedi Khama's proposal for a "Bechuanaland Protectorate Military Labor Corps" under British command was now seriously examined. ${ }^{45}$ Khama's proposal had sat on the back burner since February 1941. The plan outlined a cost-effective method to raise one brigade (6 companies

40

41

42

43

Ibid., pp 74-5.

SADF Archives, UWH, Box 159.

Lt-Gen George Brink's papers. Manpower and Organization quoted in Martin and Orpen, South Africa at War, 104. Men from the NMC were enlisted as motor and animal transport drivers, guards, stretcher-bearers, medical and hygiene personnel, and officers' batmen. BNA S 135/3 Box No. 135, Native Military Corps: terms and conditions of service.

Ibid. A special NMC unit composed of miners was sent to Syria to construct a tunnel through a mountain in 1941. See S. Horwitz, "The Non-European War Record in South Africa," Handbook of Race Relations in South Africa, p 543.

BNA S 136/1 War with Germany, African Auxiliary Pioneer Corps. Minutes of Resident Commissioner's Conference on 10 April 1941; also Morton and Ramsay, The Birth of Botswana, p 104.

Tshekedi Khama's proposal was first brought to the attention of the Resident Commissioner at Mafeking on 3 March 1941. Nothing was done until General Wavell's plea several months later. BNA S 135/7 War with Germany: T.K.'s Proposal for Native Corps. 
consisting of 145 recruits each) on a trial basis. ${ }^{46}$ Khama wanted the brigade totrain in the Protectorate and then be transferred to British authorities as fighting forces, labor or transport corps, or medical auxiliaries. Khama proposed to finance the new force through a graduated tax to come from two sources: tax payers and wage earners. This plan, although never implemented as designed, served as the catalyst that influenced British military officials to consider forming the African Auxiliary Pioneer Corps as an Imperial unit.

Once the High Commissioner received approval from the Secretary of State for Dominion Affairs, and agreements were reached with the Union Government, the Resident Commissioners in the HCT began recruiting for the newly formed "Pioneer Corps." The High Commissioner informed British military authorities that they might be able to raise 10,000 men in Basutoland, 3,000 in Bechuanland, and 500 in Swaziland. ${ }^{47}$ Plans and policies regarding the Corps were negotiated between British and South African leaders, with the cooperation of African leaders in each territory. The terms and conditions of military service were to be identical to the SANMC in order to provide European officers key leadership positions, and the Union would facilitate that process by releasing territory officials serving in the UDF. This was a crucial point because the Resident Commissioners from the HCT were adamant that South African officers were not to command their troops. The High Commissioner stressed that the AAPC would have access to South African resources, especially in regards to military clothing and equipment. Additionally. Special recognition and privileges would be afforded the AAPC. Unlike the SANMC, 25\% of AAPC units could be armed for self-defense once they reached the Middle East, according to agreements reached with General Smuts. ${ }^{48}$ Since any unit operating in the desert was open to sudden attack by a mobile column, in retrospect it is hard to imagine how unarmed men could be expected to serve at all. ${ }^{49}$

On 15 June 1941, the Resident Commissioner of Bechuanaland and the chiefs were informed that authorization to mobilize had been granted by British authorities. Out of the negotiations conducted between South Africa and Great Britain over the employment of the AAPC during the preceding months, new

46

Ibid. The complete plan is outlined in this file.

BNA S 136/1 Record of Conference in Resident Commissioner's Office. 10 Apr 1941.

HCT troops were to be armed with a rifle, or alternatively, some would be armed with machine guns. They were not issued arms in the territories. BNA DCG $3 / 2$ Box No. 3, African Auxiliary Pioneer Corps: Enlistment of Africans.

Despite army policies against arming Africans, many soldiers possessed weapons, including South African blacks. Captured guns were given to Africans for training and personal use. Jack Kros, With the South Africans from Taranto to the Alps (Rivonia, South Africa: Ashanti Publishing, 1992), pp 153-4; photo in James Ambrose Brown, Retreat to Victory: A Springbok's Diary in North Africa (Johannesburg: Ashanti Publishing, 1991), p 53. 
conditions of service emerged. The British War Office, concerned over conflicts of interest with Union officials, determined that all AAPC recruits were bound by the British Army Act (not Union army regulations), that an Oath of Allegiance to the Crown was mandatory, and military service could be anywhere in the world. ${ }^{50}$ These conditions of service guaranteed that British army officials would maintain command and control over the men assigned to the HCT Pioneer units. It effectively separated the AAPC from any official association with the SANMC. Within six months, Bechuanaland had organized 15 AAPC companies (5,000 men) and they were on their way to the Middle East. The quota would later be raised to 10,000 men from Bechuanaland alone. As the recruitment campaign continued, it was more difficult to acquire young men who met the physical qualifications for military service especially among those who had worked on the mines in South Africa. Here lie another problem for recruiting officials and chiefs who were trying to meet the imperial quotas. Military recruitment ran counter to mining recruitment.

As an emergency recruiting measure, the Resident Commissioner requested that the Native Recruiting Corporation (NRC) as well as independent recruiting agencies stop all recruiting for the mines in the Protectorate. ${ }^{51}$ It was estimated that over 12,000 men were working for the mines and on farms in South Africa in $1939 . .^{52}$ It was hoped that the NRC would return the men from the mines as they completed their contracts. ${ }^{53}$ The Witwatersand Native Labour Association (WNLA) was, however, allowed to recruit as usual in other areas in Africa. In order to make travel to South Africa more difficult, the police were ordered to suspend all visiting passes to the Union; and no passes were issued except to those ineligible for military service. The chiefs were asked to arrange kgotla meetings attended by the Resident Commissioner to explain the urgent manpower needs of the British government.

Despite the carrot and stick methods of recruiting that were employed by colonial officials, the government was unable to find sufficient recruits. To compound the problem, the Bechuanland administration was very concerned about maintaining the flow of labor to the mines while meeting military quotas. General Smuts stressed to the Gold Producers Committee that gold production needed to remain at the existing standard throughout the war. In 1941, Lord Harlech promised the President of the South African Chamber of Mines that if recruiting exceeded 5,000 men in Bechuanaland they would discuss mine requirements before raising additional companies. ${ }^{54}$ The Chamber was supportive of army recruiting, as it had

BNA S 136/1, Minutes of Conference Held by the Resident Commissioner at Gaberones, 20 Jun 1941.

BNA DCG $3 / 2$ Box 3, Letter from Forsyth Thompson to Theron's Native Labour Organization 
been in World War One, but refused to do anything that might influence those already on the mines to join the army. ${ }^{55}$ When army requirements were subsequently increased, the Bechuanaland authorities suspended all recruiting for the mines indefinitely. ${ }^{56}$

Concerned about the impact of the decision, Resident Commissioner Forsyth Thompson wrote District Commissioner Nettleton, "the need of the mines for labor is acute, and the longer recruiting is delayed for the mines the more damaging it is financially to the Protectorate. We have obligations to the mines and the mine authorities are getting a little restive." ${ }^{57}$ At least some members of the colonial system, felt that they should interfere as little as possible with the principle of a "free market" in labor. In the administration's view, mine labor was just as important as recruiting for the AAPC because it provided gold for the war effort. The chiefs also had financial concerns regarding the reduction of migrant labor. The charge that a number of leaders benefited from the "selling" of their people into migrant labor was not entirely without foundation. A labor report from the BaNgwato district for 1939, claimed that L16,355 was forwarded to the district through the voluntary deferred pay system, besides a considerable sums of money were sent as remittances to relatives and further sums were brought back from the mines themselves. Thus the Resident Commissioner could write in 1936, "I understand that some of our chiefs do receive remuneration from the recruiting corporations." ${ }^{58}$ Although the colonial administration officially maintained that no one was being forced out of the Protectorate to work, they knew that some chiefs were sending people out to work in order to collect taxes, and that some were even being employed by South African recruiting companies. ${ }^{59}$ According to David Massey, "there were active collaboration between the administration, chiefs, and the South African mining companies in using the hut tax to force men out to work. There can be little doubt that the profit motive took precedence over loyalty to the crown with some colonial officials and chiefs. Local villages stood to gain from wages repatriated from the South African mines. Others were adamantly opposed to economic arguments; they considered filling army labor requirements of first importance during the war. Tshekedi Khama wrote his views to the DC in Serowe:

Ibid.

General Auchinleck, C-in-C Middle East had written the High Commissioner in May 1942 that 90,000 additional non-European troops were needed. He asked the HCT to raise their contribution an additional 15,000 men. He thought that the agricultural population of the HCT had been exploited to the maximum and that the mines were therefore the only remaining source. BNA S 136/6, Letter from Gen Auchinleck to HC, May 1942.

BNA S 136/5, Letter from Forsyth Thompson to DC Nettleton at Serowe, 31 Oct 1941.

BNA S 177/1/1, 6 Oct 1936.

DCS 24/21, Report for BaNgwato District, 8 Mar 1940. 
...I agree that recruiting for the mines can now be without special permission as far as my Territory, except Bokalaka and Botheti, is concerned. I am sorry to exclude Bokalaka and Botheti; I fully realize mining is an important work but nearly as important as the call for active service; we are fighting for the national honor of our African people. $^{60}$

Conflicting goals regarding the maximum benefit to be derived from the Protectorate's manpower plagued the administration throughout the war. Figures published officially by the Union Government show that the supply of labor from Bechuanaland to the mines was significantly reduced during the war. The number of BaTswana laborers going to South Africa dropped from 19,898 in 1940 to 12,792 in $1943 .{ }^{61}$ The DC at Gaborone estimated in 1943 that $80 \%$ of the men fit for military service, mine and other hard labor, and farm work were absent on long service contracts. He stressed, "if this state of affairs continues very long, serious consequences to the social and economic life in Bechuanaland will result." ${ }^{2}$

New demands for labor (war and mines) continued to pour in from 19431945 , so what was the solution? Unfortunately, there were no mandated limits on migrant labor to stop young men from going to South Africa. In some British colonies there were set limits on male migration. In Bechuanaland the unofficial limit was et at $30 \%$ or 20,000 men for the war effort and mines. ${ }^{63}$ One obvious solution for military recruiters, was to canvas areas where there was a surplus population. Tshekedi Khama argued "the mines needed to make greater sacrifices during the war, and return men to the Protectorate. He stressed that if free mine recruiting was allowed to continue, it would open the door for a minority who deliberately avoided military service in the AAPC and who were, in fact, deserters from his own regiments!",64

A factor related to the migrant labor issue was the rate of pay offered for military service. According to DC Ellenberger, "the average MoTswana is a very unskilled laborer and there is little scope for his services within the territory. The majority of able-bodied males seek employment beyond the borders of the Territory as farm hands and mine laborers." 65 The average monthly wage for Africans

BNA S 136/5, Letter from T. Khama to DC at Serowe, 2 Nov 1941.

J. Shuckburgh, "Civil History of the War," 43. The total population was estimated at 257,064 in 1944 .

BNA DCG 3 /4, Annual Report, 1941.

Shuckburgh, "Civil History," 43.

Also BNA S 136/6, Notes on meeting held by HC, 13 May 1942.

BNA S 136/5, Letter from DC Nettleton to Forsyth Thompson, Mafeking, 1 Nov 1941.

BNA DCS 24/21, Annual Report DC at Serowe, 1939. 
working in the mines was about equal to that of military members but it was not enough for some to risk their life. One soldier complained that those who did enlist in the army were not appreciated, "we have answered the call, irrespective of low wages, and had to leave decent occupations to join the army. ${ }^{166}$ Africans knew they earned substantially less than European soldiers. The issue of poor pay received frequent news coverage during the war, "the limited response by the urban native population to the appeal of military recruits for the Army arose out of the hopelessly inadequate pay of the native recruit," said Mrs W.G. Ballinger (South African M.P. $)^{67}$ "Push/pull" factors such as drought, health and physical fitness, labor issues and local political conditions also hampered recruiting and colonial administrators were never quite sure how to manipulate them to their advantage.

Opposition to AAPC recruiting continued throughout the war in the HCT. As the years passed, the families increasingly missed their relations. Those men who had fled to South Africa expressed their dissatisfaction through African newspapers. BaTswana refugees accused their leaders of forcing people to go to war. Tshekedi Khama was outspoken about what he called "subversive" elements in South Africa. Writing to the DC in Serowe, Tshekedi confided that

He had been horrified and amazed to discover during his visit to Cape Town the attitude towards the war taken up by the great majority of African and Coloured population in the Union. He understood from a variety of reliable Informants that they don't regard this as their war; since no government could have their interest less at heart or adopt a more repressive policy than the Union government. ${ }^{68}$

Newspaper articles in The Bantu World reflect a heated debate regarding the war and African participation between 1939-45. The fact that South Africa had a larger, literate politicized African population did not escape the notice of Tshekedi Khama. Dissension of this nature would have been unacceptable in the eyes of the administration and some chiefs in Bechuanaland.

In conclusion, the complex nature of mobilizing a society for war is evident in the political, economic, and social upheavals within Bechuanaland and the region in the early years of the Second World War. Colonial administrators, chiefs and many young men with the HCT were forced to adapt to new demands and expectations. Mobilization reflects many of the tensions within the colonial system in southern Africa that have their origins in previous historical events. One trend is

"African Soldiers and Their Fellowmen," The Bantu World (21 Feb 1942), p 4.

67 "African Soldiers and Poor Pay," The Bantu World (8 Nov 1940), p 1.

BNA S 136/7, extract from Inkululeko/Freedom (published by the Communist party of S.A.), attacking the war effort in Bechuanaland and Basutoland as found in D. Kiyaga-Mulindwa, "The Bechuanaland Protectorate and the Second World War" JICH, XII, (3 May 1984), 52. Copies of this newspaper (1940-65) are available at Cape Town University Library and the State Library, Pretoria.
} 
particularly evident, Great Britain relied on its African colonies for military manpower when the exigencies of war demanded it. In other words, the major impetus for mobilization in the HCT undoubtedly came from the pressures and demands arising out of the war, especially by the end of 1941 when the war moved to North Africa and beyond. As in the past, the British failed to develop an independent, egalitarian policy towards African armed forces in the region because of the political, economic and social tensions emanating from South Africa. Because of their limited vision, distrust and political paralysis, British colonial and military leaders offered only a limited military role to the HCT soldiers. ${ }^{69}$ Despite their efforts to couch these limited opportunities in attractive ways, the HCT collectively viewed the war as another colonial burden. Experience: Ghanaian Soldiers in World War II" in the Journal of Modern African Studies, 25, 1, (1987), p 163. 